\title{
The Effect of the Implementation of Enterprise Risk Management Integrating With Strategy and Performance on Fraud Prevention (Case Study on Pt. Taspen (Persero)
}

\author{
Pradila Syahfitri Harahap $^{1 *}$, Nengzih Nengzih ${ }^{2}$ \\ ${ }^{1,2}$ Department of Accounting, Faculty of Economic and Business, Universitas Mercu Buana, Jakarta, Indonesia
}

DOI: 10.36348/sjef.2021.v05i04.002 | Received: 06.03.2021 | Accepted: 02.04.2021 | Published: 06.04 .2021

*Corresponding author: Pradila Syahfitri Harahap

\section{Abstract}

This study aims to examine the effect of implementing corporate risk management on fraud prevention. This study adopts the COSO framework for risk management system analysis. This research is a quantitative study with a case study approach. The sample in this study were 99 employees who served in 5 business units using the simple random sampling method. The data analysis method used is Structural Equation Modeling (SEM). Based on the results of hypothesis testing, it shows that risk management has a significant effect on fraud prevention. The risk management implemented by PT Taspen can be categorized as good. However, it is still necessary to evaluate, monitor and further refine the company's risk management framework.

Keywords: COSO, ERM Framework, Risk Management, Fraud Prevention.

Copyright () 2021 The Author(s): This is an open-access article distributed under the terms of the Creative Commons Attribution 4.0 International License (CC BY-NC 4.0) which permits unrestricted use, distribution, and reproduction in any medium for non-commercial use provided the original author and source are credited.

\section{INTRODUCTION}

Companies face various kinds of risk threats, both from within and from outside. According to Sutanto in Sirait \& Susanty's research [1], risk is an uncertainty that cannot be avoided in the operation of a business and can also be said to be a part of company activities where risk not only contains negative impacts but results in risks that have a positive impact. Nanto [2] in his research stated that risk can be caused by very uncertain economic, political and technological conditions. Currently, the perpetrators of fraud are not only limited to the upper class, but many have touched the lower levels of employees. Fraud is not only a decrease in organizational assets, but can affect the reputation of the organization itself. Fraud can occur anywhere, not limited to large companies but can occur in small organizations such as cooperatives. Seeing the increasing number of phenomena with increasingly clever fraud modes, it seems it is time for companies to implement a reliable and up-to-date control system. Reliable risk management capability is one of the core competencies that management must possess to create value (value creation) for a company. One of the efforts that can be made to minimize the occurrence of fraud is by implementing Enterprise Risk Management (ERM).

Shasank Srivastava [3] in his journal entitled Qualitative Methodology Pertaining to Risk Assessment in Small Enterprises as per Indian Industrial Scenario examines risk assessment using the Enterprise Risk Management model in small companies in India. The result of this research is that an efficient ERM enables management to effectively handle and exploit the risks and opportunities associated with uncertainty, thereby increasing the value for its shareholders. ERM is the organization's ability to understand and control the level of risk it takes in managing business strategy, coupled with accountability for the risks it takes. Companies must remain consistent in implementing the principles of GCG and risk management and continue to improve their implementation throughout the company's business and ensure that each activity is free from gratification, fraud and corruption, collusion and nepotism practices.

The ERM framework is directed towards achieving company goals which are divided into 4 categories, namely strategic, operations, reliability of reporting, and compliance with laws and regulations (compliance). This categorization is expected to allow companies to focus on each aspect of ERM [4]. ERM implementation in a company will be able to help control management activities so that the company can minimize the occurrence of fraud that can harm the company. 
Pradila Syahfitri Harahap \& Nengzih Nengzih., Saudi J Econ Fin, Apr, 2021; 5(4): 141-147

The basic concept of corporate risk management has been widely applied in several industries. In carrying out internal control, it is necessary to have a tool in the form of a risk management framework which is commonly called a Framework. The first ERM framework published was ERM - Integrated Framework which was published in 2004. However, along with the rapid development of business, it is necessary to update the framework. Priantara [5] states that reforms are needed to respond to the development of ERM as a system, the development of business risks that are fast and increasingly unpredictable, while business or operational demands are not reduced, and to meet organizational aspirations that require an ERM system that is in line with current issues . Finally, COSO made an update to the ERM framework.

This framework is named ERM - Integrating with Strategy and Performance. The main contribution of this new framework is to more specifically integrate ERM with the setting of corporate strategy, governance and culture.

This confirms that ERM cannot run well without an integrated corporate strategy. One of the greatest sources of risk for companies today arises from the context of their strategic plans. The greater the level of integration between strategy and risk management, the more likely the company will be successful in implementing its strategy [6]. By integrating the strategy and implementation of risk management, it is hoped that it can be maximized in identifying and mitigating fraud risk.

\section{LITERATURE REVIEW AND DEVELOPMENT HYPOTHESIS Agency Theory}

Agency theory emphasizes the importance of company owners (shareholders) handing over the management of the company to professionals called agents who better understand their daily business. In the agency model, a system is designed that involves both parties, namely management and owners. Jensen and Meckling define an agency relationship as a contract in which one or more people (principal) engage other people (agent) to perform some service on their behalf which involves delegating decision-making authority to the agent [7]. As a result of this agency relationship, agency problems arise, in which case the agent will try to maximize his own interests while ignoring the interests of the principal, even though the main objective of a company is to maximize the welfare of the owners of capital. Conflicts of interest that occur in companies can lead to undesirable variations in risk, including, among other things, the improper use of company assets, fraud, and insufficient competency management. Therefore, a form of control is needed to control the agent's actions.

\section{Fraud Triangle Theory}

The basic fraud theory is the fraud triangle theory. The Fraud Triangle theory put forward by D. R. Cressey in 1953 states that there are three appropriate factors to describe the reasons why someone commits fraud, namely the existence of pressure (incentive/pressure), opportunity (opportunity) and rationalization (rationalization). Pressure / motive is an incentive that encourages people to cheat because of lifestyle demands, financial powerlessness, gambling behavior, trying to beat the system and job dissatisfaction. Opportunity is a situation or condition that allows fraud to occur.

Opportunities occur because of weaknesses in internal control, ineffective management supervision, or abuse of position or authority. The thing that stands out the most here is in terms of internal control. Poor internal control will give people the opportunity to commit fraud. Rationalization is an important element in the occurrence of fraud, in which perpetrators seek justification for their actions. Attitude or character is what cause one or more individuals to rationally commit fraud.

\section{GONE Theory}

The GONE theory is a refinement of the Triangle Fraud theory which reveals why a person commits fraud. According to the GONE theory, there are 4 factors that can encourage someone to commit fraud, namely, Greed, Opportunity, Need, Exposure. Greed and Need are factors that relate to individual perpetrators of fraud or are called individual factors. Meanwhile, the opportunity and exposure factors are factors that relate to organizations being victims of fraudulent acts or referred to as generic factors [8]. Greed related to the greed and greed of the perpetrators of corruption that potentially exist in everyone. Opportunity or opportunities related to systems that provide holes for corruption, which are related to the state of the organization/agency or community environment that opens opportunities for someone to commit fraud. Need is a mental attitude that is never enough, full of consumerism, and always full of needs that never end. Exposure is related to the low penalties for the perpetrators of corruption, penalties that do not deter the perpetrators and others, and minimal deterrence effect.

\section{Enterprise Risk Management}

Enterprise risk management (ERM) is a planbased business strategy that aims to identify, assess and prepare for all risks and other potential disasters, both physical and figurative, that can disrupt the operations and objectives of the organization. Aditya \& Naomi [9] stated that ERM is often referred to as Integrated Risk Management (IRM) and Strategic Risk Management (SRM) which offers a concept of considering the entire company's risk portfolio in an integrated and holistic 
Pradila Syahfitri Harahap \& Nengzih Nengzih., Saudi J Econ Fin, Apr, 2021; 5(4): 141-147

manner, thus risk mitigation can be early and comprehensive. Handoko et al. [10]. states that the use of the ERM application can carry out risk assessments, detect the frequency of risk occurrences, the resulting impact, calculate the risk value and provide risk responses. The main difference of this latest COSO ERM lies in how to integrate and integrate an enterprise risk management system into business and operations starting from the time of planning a business strategy or organizational strategy and making ERM or an enterprise risk management system function effectively at all layers or levels of the organization [11]. The 2017 version of COSO's ERM consists of five components that have 20 principles in them. The five components are;

- Governance and organizational culture that can support the implementation of the organizational strategy and efforts to achieve its performance.

- Formulation, strategy, and organizational goals that must align ERM with the organization's business strategy and objectives in the strategic planning process.

- $\quad$ Performance that consider risk before executing business strategies.

- Review and revise ERM to ensure whether ERM is allied and able to provide value in the planning cycle up to the achievement of organizational strategies and objectives.

- Information and communication as well as effective to all levels of the organization according to the level of information required by each in a fast, complete, and accurate.

By implementing these five components, companies can rectify and improve the quality of organizational performance, supervisio, and reduce the risk of fraud within the organization.This statement is supported by research results from Tita Djuitaningsih [12], Bambang Leo Handoko et al. [13], and Umaru Hussaini et al. [14] showing that implementing ERM into strategy can identify risks early and improve organizational performance.

\section{H1: Enterprise Risk Management affects to Fraud Prevention}

\section{Definition of Fraud}

ACFE in the research of Yelvionita, Utami, and Mappanyuki [15] defines fraud as irregularities and acts against the law, which are carried out intentionally for certain purposes such as deceiving or misleading other parties, by someone both from within and outside the organization. Hussaini et al. [16] revealed that fraud is carried out by organizations and individuals to avoid payment and eliminate services to obtain services, property, or money to secure personal or business benefits. In order for the goals set by top management to be achieved, the security of company assets is guaranteed and operational activities can be carried out effectively and efficiently, management needs to implement good internal controls. If the internal control of a business entity is weak, the possibility of fraud and error is very high. Soekrisno Agoes [17] stated that fraud can occur in various forms, such as: intentional error, unintentional error, employee and management fraud, white-collar crime, embezzlement, computer crime, and others.

\section{Fraud Prevention}

Yuniarti [18] defines fraud prevention as a series of programs designed to prevent or at least control this fraud. This strategy is pursued by controlling the factors that drive fraud by creating conditions that facilitate detection and avoidance of accommodators and promote fraud prevention. The responsibility for carrying out fraud prevention rests with management, leadership, and other authorities interested in achieving organizational goals [19]. Nugroho et al. [20] revealed that fraud can cause losses for companies, such as financial losses to damaged reputation, therefore every company tries to implement a good risk management system. According to Tunggal in Fitri's research [21] To prevent fraud, there are several governance systems, including:

1.Honest culture and high ethics.

2.Management's responsibility to evaluate fraud prevention.

3.Oversight by the audit committee.

From the description above, it can be seen that with the prevention efforts implemented by the company it can reduce the chances of fraud, because every act of fraud can be detected quickly and well anticipated by the company.

\section{RESEARCH METHODOLOGY}

This section describes the types of research, data sources, data collection techniques, and methodologies used to test the effects of this research.

\section{Types and Objects of Research}

This type of research is quantitative research. Quantitative research involves measuring the quantity of characteristics that can be used as features for a research study. In contrast to qualitative, quantitative research uses statistical analysis on parameter values to arrive at conclusions [22]. The research was conducted at PT. TASPEN (Persero) which is headquartered in Cempaka Putih, Central Jakarta.

\section{Data, Population, and Sample}

The data used in this study are primary data in the form of a questionnaire. Data were collected using observation / observation techniques, interviews via electronic media, and distributing questionnaires in google form format. The population in this study were employees of PT. TASPEN which consists of managers, supervisors, and staff who work in related divisions, totaling 131 employees. The sample in this 
Pradila Syahfitri Harahap \& Nengzih Nengzih., Saudi J Econ Fin, Apr, 2021; 5(4): 141-147

study was taken by simple random sampling. By using the Slovin formula, the total sample size is 99 people.

\section{DATA ANALYSIS}

The data analysis method used in testing the relationship between variables in this study is the Structural Equation Model (SEM) with data processing techniques using Partial Least Square (PLS). Data analysis includes testing the validity and reliability of the instrument, evaluating the inner model and outer model and testing the hypothesis.

\section{RESULTS AND DISCUSSION}

\section{Evaluation of the Measurement Model (Outer Model)}

Evaluation of the measurement model or outer model is carried out to assess the validity and reliability of the model. The outer model with the reflection indicator is evaluated through convergent and discriminant validity of the latent construct-forming indicators and composite reliability and Cronbach alpha for the indicator block. The validity test in this study is convergent validity and discriminant validity, while the reliability test is composite reliability and cronbach's alpha.

\section{Validity Test \\ Convergent Validity Test}

The measurement model with reflective indicators is assessed based on the loading factor of each latent construct forming indicator assessed based on the loading factor of each latent construct forming indicator. A latent construct is considered to have a good convergent validity if the loading factor value is more than 0.7 and is significant.

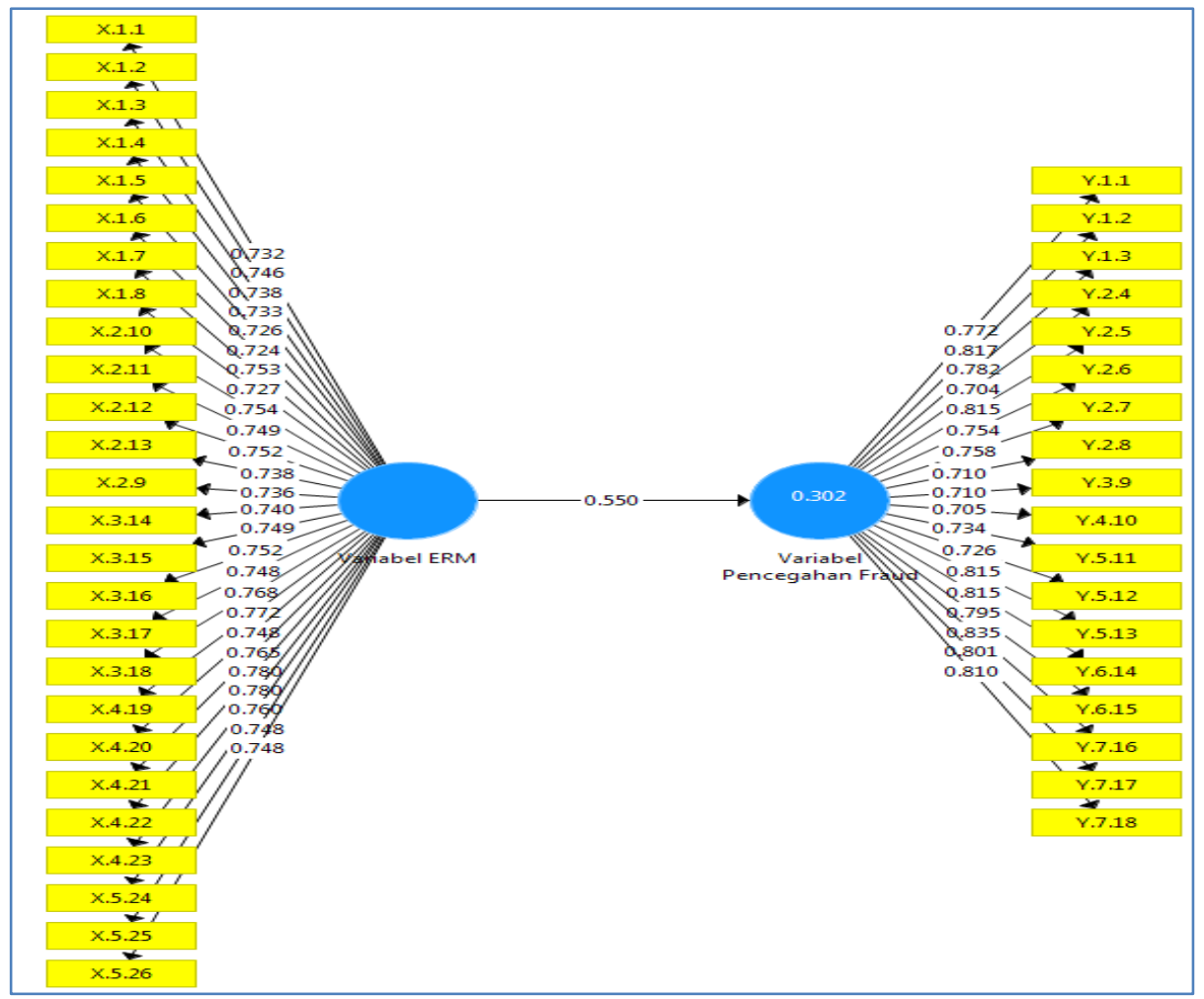

Fig-1: Outer Loading

Based on the results of the analysis, all indicators have a loading factor of $>0.7$, which means that these indicators are valid in measuring the ERM construct and fraud prevention so that these indicators can be used in this study.

\section{Discriminant Validity Test}

A good discriminant validity is shown from the square root of AVE for each construct which is greater than the correlation between constructs in the model, that is, by looking at the cross loading of each construct, it must be> 0.70 [23].
Table-1: Discriminant Validity Test Results

\begin{tabular}{|l|l|l|}
\hline Variable & $\begin{array}{l}\text { ERM } \\
\text { Variable }\end{array}$ & $\begin{array}{l}\text { Fraud } \\
\text { Prevention } \\
\text { Variable }\end{array}$ \\
\hline ERM Variable & 0,749 & \\
\hline Fraud Prevention Variable & 0,550 & 0,771 \\
\hline
\end{tabular}

Based on the data presented in the table above, the results show that the cross loading value is in accordance with the requirements, which is above 0.70 . The results of this test can be concluded that the two variables have good discriminant validity, namely the 
ERM variable of 0.749 and the fraud prevention variable of 0.771 .

\section{Reliability Test}

Ghozali [24] states that the reliability test is to prove the accuracy, consistency and accuracy of the instrument in measuring the construct of a reflective indicator which is declared reliable if it has cronbach's Alpha and D.G Rho values if the value is > 0.60 .

\begin{tabular}{|l|l|l|l|l|l|}
\hline Item & Variable & $\begin{array}{l}\text { Cronbach's } \\
\text { Alpha }\end{array}$ & $\begin{array}{l}\text { Rho } \\
\text { A }\end{array}$ & $\begin{array}{l}\text { Composite } \\
\text { Reliability }\end{array}$ & $\begin{array}{l}\text { Average Varian } \\
\text { Extracted (AVE) }\end{array}$ \\
\hline $\mathrm{X}$ & $\begin{array}{l}\text { Enterprise Risk Management- } \\
\text { Integrating with Strategy and } \\
\text { Performance }\end{array}$ & 0,969 & 0,971 & 0,971 & 0,562 \\
$\mathrm{Y}$ & Fraud Prevention & 0,961 & 0,974 & 0,963 & 0,595 \\
\hline
\end{tabular}

From the table above shows that the value of Cronbach's alpha for the constructs of variable $\mathrm{X}$ and variable $\mathrm{Y}$ are all $>0.7$ so it can be concluded that all the constructs in this study have good reliability in accordance with the minimum value limit indicated. The AVE values for variable $\mathrm{X}$ and variable $\mathrm{Y}$ in this study are all above 0.50 so it can be said that they meet the reliability and validity in accordance with the minimum value limit indicated.

\section{Structural Model ( Inner Model)}

Inner Model aims to predict the hypothesized relationship between latent variables. The test for the structural model (inner model) used in this study is $\mathrm{R}$ Square, Hypothesis Testing, Effect Size (f square), Prediction Relevance (Q Square).

\section{R2 Analysis}

To determine the effect of enterprise risk management-integrating with strategy and performance on fraud prevention, it can be seen from the R-Square (R2) value in the following table.

Table-3: R-Squares (R2) Fraud Prevention

\begin{tabular}{|l|l|l|}
\hline Variable & R Square & $\begin{array}{l}\text { Adjusted R } \\
\text { Square }\end{array}$ \\
\hline $\begin{array}{l}\text { Fraud Prevention } \\
\text { Variable }\end{array}$ & 0,302 & 0,295 \\
\hline
\end{tabular}

Table 3 above shows that the construct of fraud prevention is influenced by $30.2 \%$ by the enterprise risk management-integrating construct with strategy and performance, while $69.8 \%$ is influenced by other constructs not included in the study. From this figure, it can be categorized that the dependent variable can be explained by the independent variable on a moderate scale.

\section{Q2 Analysis}

Evaluation of the measured Goodness of Fit
Predictive relevance value (Q2) is calculated using a formula as follows:

$$
\begin{aligned}
& \mathrm{Q} 2=1-(1-\mathrm{R} 21)(1-\mathrm{R} 22) \\
& \mathrm{Q} 2=1-(1-0,550) \\
& \mathrm{Q} 2=1-(0,45) \\
& \mathrm{Q} 2=0,550
\end{aligned}
$$

The results of the calculation of $\mathrm{Q} 2$ show that the value of Q2 is $0.550 . \mathrm{Q} 2$ value is more a greater than 0 (zero) indicates that the model is said to be quite good and rated as relevant.

\section{F2 Analysis}

In assessing models with smartpls 3.2.9 starting with looking at the R-square for any dependent latent variable. Change the $\mathrm{R}$-square value can be used for assess the effect of the independent latent variables the dependent latent variable does it have a substantive effect.

Table 4. Results of F2 Square

\begin{tabular}{|l|l|}
\hline Variable & Fraud Prevention Variable \\
\hline ERM Variable & 0,433 \\
\hline
\end{tabular}

Based on the table above it can be stated that the influence of the Enterprise Risk variable Management-Integrating with Strategy and Performance against the Fraud Prevention variable has an F2 of 0.433 in category "medium".

\section{Hypothesis Test}

Hypothesis testing in this study by doing an impact analysis Variable Enterprise Risk ManagementIntegrating With Strategy and Performance against the Fraud Prevention variable with correlation technique using smartpls 3.2.9 and the resulting PLS output can be seen in the table as follows. 
Pradila Syahfitri Harahap \& Nengzih Nengzih., Saudi J Econ Fin, Apr, 2021; 5(4): 141-147

Table-5: The Results of Testing the Influence of
Enterprise Risk Management-Integrating With
Strategy and Performance on Fraud Prevention
(Path Coefficient)
\begin{tabular}{|l|l|l|l|l|}
\hline $\begin{array}{l}\text { Path } \\
\text { Coefficient }\end{array}$ & $\begin{array}{l}\text { t- } \\
\text { count }\end{array}$ & $\begin{array}{l}\text { table } \\
\text { tal }\end{array}$ & Ho $_{\mathbf{o}}$ & H $_{1}$ \\
\hline 0,550 & 5,573 & 1,984 & Received & Rejected \\
\hline
\end{tabular}

The table above shows the results of hypothesis testing for the Enterprise Risk ManagementIntegrating With Strategy and Performance variable amounting to 5.573 .

Ho: Pyx1 = 0 Enterprise Risk Management-Integrating With Strategy and Performance has no effect on Fraud Prevention.

H1: Pyx $1 \neq 0$ Enterprise Risk Management-Integrating With Strategy and Performance has a positive effect on Fraud Prevention.

This figure is above the table 1.984 means hypothesis (Ho) which states the variable Enterprise Risk Management-Integrating With Strategy and Performance no affect Fraud Prevention unacceptable and conversely accept the alternative hypothesis (H1) that is declare Enterprise Risk Management-Integrating With Strategy and Performance positive effect on prevention Fraud accepted. The magnitude of the variable influence Enterprise Risk ManagementIntegrating With Strategy and Performance such as shown in the table above consists of a direct effect of 0.550 or $55 \%$ and the indirect effect of $45 \%$ by other variables. This value is based on guidelines on the interpretation of coefficients the correlation is on the coefficient interval between 0.40 - 0.599 "moderate" category, then hypothesis (H1) which states the variables Enterprise Risk Management-Integrating With Strategy and Performance is influential positive and significant towards the variable Fraud prevention is included in the category"Medium".

\section{CONCLUSION}

Based on the tests that have been done, it can be concluded that Enterprise Risk Management has an effect on Fraud Prevention. PT. Taspen involves risk management in strategic planning, application, and final process. This is what makes risk management good. Risks are identified more quickly so that prevention and treatment efforts can be carried out. Due to good risk management, the risk of fraud can also be overcome, this has an impact on the company, namely by increasing company performance. The risk of fraud that often occurs at PT Taspen comes from an external scope such as faked claims. To overcome this, some of the efforts made by PT Taspen were conducting briefings and supervision with the Head of the relevant fields, evaluating all activities carried out whether they were in accordance with the SOP, and resolving complaints that were received within two days. For this reason, the company is expected to continue to maintain and improve the quality of risk management.

Some suggestions that can be applied in future research to expand research not only in SOE but also other companies that implement ERM, conduct research on unit analysis that has never been done in previous research, review the methods used in preventing fraud, and use measuring tools risk management other than Enterprise Risk Management.

\section{REFERENCES}

1. Sirait, N. M., \& Susanty, A. (2016). Analisis Risiko Operasional Berdasarkan Pendekatan Enterprise Risk Management (ERM) pada Perusahaan Pembuatan Kardus di CV Mitra Dunia Palletindo. Industrial Engineering Online Journal, 5(4).

2. Nanto, W. (2015). Company Characteristics and Determining Factors in the Application of the Enterprise Risk Management Framework in the Empirical Study of the Mining Sector and the Infrastructure, Utilities and Transportation Sectors Listed on the Indonesia Stock Exchange in 2014. Master of Management Study Program, Faculty of Economics and Business UI, 2015.

3. Srivastava, S. (2017). Qualitative Methodology Pertaining to Risk Assessment in Small Enterprises as per Indian Industrial Scenario. International Research Journal of Engineering and Technology (IRJET), 4(8), 1877-1886.

4. Gabriela, D. (2018). Analysis of the Implementation of Enterprise Risk Management in Supporting Company Performance: A Study on the Astra Group. Master of Management Study Program, Faculty of Economics and Business UI.

5. Priantara, D. (2017). Get to know COSO's Enterprise Risk Management Framework. Accessed on 12 May 2019 and 26 May 2019 from the World

WideWeb:https://iiaindonesia.org/mengenal kerangka-kerja-enterprise-risk-management-alacoso/.

6. Do, Ha., Railwaywalla, M., Thayer, J. (2016). Integration of ERM with Strategy- Case Study Analysis.North Carolina: Poole College of Management.

7. Triyuwono, E. (2018). Contract Process, Agency Theory and Corporate Governance (Contracting Process, Agency Theory, and Corporate Governance). SSRN Electronic Journal, January, Page: 0-14.

8. Agoes, S. (2017). Auditing: Practical Guidelines for Accountant Audit by Public Accountants $\left(5^{\text {th }}\right.$ ed). Jakarta: Salemba Empat.

9. Aditya, O., \& Naomi, P. (2017). Implementation of Enterprise Risk Management and Company Value in the Construction and Property Sector. Esensi: Journal of Business and Management, 7(2): 167180. 
Pradila Syahfitri Harahap \& Nengzih Nengzih., Saudi J Econ Fin, Apr, 2021; 5(4): 141-147

10. Handoko, B. L., Septianto, D., \& Alyssa, A. (2019). Applications for the Use of the Integrated Framework Coso Enterprise Risk Management (ERM) to Detect the Risk of Fraud in Unusual Transactions of Pt. Doremi Pizza Indonesia. DeReMa (Development Research of Management): Management Journal, 14(1), Page: 134.

11. COSO. (2018). Enterprise Risk Management: Applying Enterprise Risk Management to Environmental, Social and Governance-Related Risks, 300-317.

12. Djuitaningsih, T. (2018). Effectiveness of Enterprise Risk Management to Prevent Fraudulent Financial Statements. Page: 1-14. Accessed on 28 Mei 2019 from WorldWideWeb:https://doi.org/10.1002/97811182 67080

13. Handoko, B. L., Septianto, D., \& Alyssa, A. (2019). Applications for the Use of the Integrated Framework Coso Enterprise Risk Management (ERM) to Detect the Risk of Fraud in Unusual Transactions of Pt. Doremi Pizza Indonesia. DeReMa (Development Research of Management): Management Journal, 14(1), Page: 134.

14. Hussaini, U., Bakar, A. A., \& Yusuf, M. B. O. (2019). The effect of fraud risk management, risk culture and performance of banking sector: A conceptual framework. International Journal of Multidisciplinary Research and Development, 6(1), 71-80.

15. Yelvionita, V., Utami, W., Mappanyuki, R. (2020). The Effect of Internal Control and Organizational Culture on Early Warning Fraud. ICORE, Jakarta, $5(1)$.

16. Hussaini, U., Abu Bakar, A., \& Yusuf, M.,B., O. (2019). The Effect of Fraud Risk Management,
Risk Culture, and Performance of Banking Sector: A Conceptual Framework. International Journal of Multidisciplinary Research and Development, 6(1), Page: 71-80.

17. Agoes, S. (2017). Auditing: Practical Guidelines for Accountant Audit by Public Accountants $\left(5^{\text {th }}\right.$ ed). Page: 226. Jakarta: Salemba Empat.

18. Yuniarti, R. D. (2017). The Effect of Internal Control and Anti-Fraud Awareness on Fraud Prevention ( A survey on inter-governmental organizations). Journal of Economics, Business \& Accountancy Ventura, 20(1), 113-124.

19. Wulandari, D. N., \& Nuryatno, M. (2018). The Effect of Internal Control, Anti-Fraud Awareness, Integrity, Independence, and Professionalism on Fraud Prevention. JRAMB, Accounting Study Program, Faculty of Economics, UMB Yogyakarta, 4(2), 117-125.

20. Nugroho, L., Utami, W., Sanusi, Z.M., Setiyawati, H. (2018). Corporate Culture and Financial Risk Management in Islamic School Enterprise (Indonesia Evidence). International Journal of Commerce and Finance, 4(2), Page: 12-24.

21. Fitri, C. I. W. (2018). The Influence of Organizational Culture and the Role of Internal Auditors on Fraud Prevention.

22. Vinayak, B., \& Mousami, M. V. (2019). Research Methodology A Practical and Scientific Approach. CRC Press. Accessed from World Wide Web http://www.crcpress.com

23. Ghozali. (2016). Multivariete Analysis Application with IBM SPSS Program.Page: 37.Semarang: Diponegoro University Publishing Agency.

24. Ghozali. (2016). Multivariete Analysis Application with IBM SPSS Program.Page: 21.Semarang: Diponegoro University Publishing Agency. 